\title{
Prevalence and predictors of vitamin D- deficiency in frail older hospitalized patients
}

\author{
Simon Friedrich Boettger, Bjoern Angersbach, Christiane Nicola Klimek, Ana Lemos Monteiro Wanderley, \\ Azim Shaibekov, Lars Sieske, Baigang Wang, Matthias Zuchowski, Rainer Wirth and Maryam Pourhassan * (1)
}

\begin{abstract}
Background: Vitamin D deficiency is known to be highly prevalent in older persons. However, the prevalence in the subgroup of frail older hospitalized patients is not clear. We sought to investigate the prevalence and predictors of vitamin D deficiency in frail older hospitalized patients.
\end{abstract}

Methods: 217 consecutively geriatric hospitalized patients with routine measurements of 25-hydroxyvitamin D [25 (OH) D] at hospital admission were analyzed retrospectively, including information of previous vitamin D supplementation and the geriatric assessment. Serum $25(\mathrm{OH}) \mathrm{D}$ concentrations $<20 \mathrm{ng} / \mathrm{ml}$ and between 20 and $29.99 \mathrm{ng} / \mathrm{ml}$ were classified as deficient and insufficient, respectively, whereas concentrations $\geq 30 \mathrm{ng} / \mathrm{ml}$ were considered as desirable. A stepwise binary logistic regression model was performed to assess the simultaneous effects of age, gender and geriatric assessments on the prevalence of low vitamin D concentration.

Results: Mean age of the cohort was $81.6 \pm 8.0$ years (70.0\% females). Mean serum 25(OH)D was $12.7 \pm 12.9 \mathrm{ng} /$ $\mathrm{ml}$. Of 167 (77\%) subjects without known previous vitamin D supplementation, only 21 (12.6\%) had serum concentrations $\geq 20 \mathrm{ng} / \mathrm{ml}$ and only 8 (4.2\%) had desirable serum concentrations $\geq 30 \mathrm{ng} / \mathrm{ml}$. In total population, 146 (87.4\%) participants were vitamin D deficient. Despite vitamin D supplementation, 22 of 50 participants (44.0\%) were vitamin D deficient and only 19 (38.0\%) had desirable concentrations of $\geq 30 \mathrm{ng} / \mathrm{ml}$. In a stepwise logistic regression analysis, only previous intake of vitamin D supplementation and high Geriatric Depression Scale score (GDS-15) were significantly associated with vitamin D deficiency.

Conclusions: In the group of frail older hospitalized patients without previous vitamin D supplementation, the prevalence of inadequate vitamin D concentrations is extremely high. Therefore, usefulness of the routine measurement of vitamin $\mathrm{D}$ status before initiating of supplementation appears to be questionable in this patient group.

Keywords: Vitamin D deficiency, Geriatric, Older, Frail, Falls

\section{Background}

Vitamin D supplementation has been shown to reduce the risk of falls and fractures in older subjects with vitamin D deficiency [1]. However, several randomized controlled trials indicated that high dose vitamin D supplementation is associated with an increased risk of falls and fractures in older individuals [2-4]. Besides the primary effects on intestinal calcium absorption, renal calcium excretion and bone mineralization, vitamin $\mathrm{D}$ has been linked to skeletal muscle strength and lower extremity function as a line of evidence to the risk of

\footnotetext{
* Correspondence: mpourhassan1918@gmail.com

Department of Geriatric Medicine, Marien Hospital Herne, University Hospital, Ruhr-University Bochum, Hölkeskampring 40, D-44625 Herne, Germany
}

falls [5]. Recently, vitamin D has also been linked to cardiac function in a prospective randomized trial [6].

Small proportion of vitamin D is obtained from food [7]. Its main natural source is the production in the sunlight exposed skin. Thus, the vitamin D skin synthesis of older persons is compromised by many factors including deprivation of sunlight exposure due to decreased mobility and a physiologic atrophy and reduction of the synthesis performance of the aging skin [8]. In addition, malnutrition is very prevalent in older persons and an alteration of nutritional intake and avoidance of fish and dairy products may also contribute to lower vitamin D concentrations.

(c) The Author(s). 2018 Open Access This article is distributed under the terms of the Creative Commons Attribution 4.0 International License (http://creativecommons.org/licenses/by/4.0/), which permits unrestricted use, distribution, and reproduction in any medium, provided you give appropriate credit to the original author(s) and the source, provide a link to the Creative Commons license, and indicate if changes were made. The Creative Commons Public Domain Dedication waiver (http://creativecommons.org/publicdomain/zero/1.0/) applies to the data made available in this article, unless otherwise stated. 
It is well known that vitamin $\mathrm{D}$ deficiency is very prevalent in the older population [9-11]. Nevertheless, there is some controversy about the optimal blood level of 25-hydroxyvitamin D [25 (OH)D]. The Institute of Medicine (IOM) suggests serum concentrations of $25(\mathrm{OH}) \mathrm{D}$ above $20 \mathrm{ng} / \mathrm{ml}$ as vitamin D sufficiency in the general population [12]. However, the Endocrine Society recommends serum concentration of $25(\mathrm{OH}) \mathrm{D}$ above $30 \mathrm{ng} / \mathrm{ml}$ as desirable whereas concentrations less than $20 \mathrm{ng} / \mathrm{ml}$ and concentrations between 20 and $30 \mathrm{ng} / \mathrm{ml}$ were considered as $25(\mathrm{OH}) \mathrm{D}$ deficiency and insufficiency, respectively $[13,14]$. Although the different relationship of serum concentration of $25(\mathrm{OH}) \mathrm{D}$ to parathyroid hormone $(\mathrm{PTH})$ levels in different age and sex groups implies various target ranges for different groups, good scientific evidence indicates that the prevalence of secondary hyperparathyroidism is lowest with $25(\mathrm{OH}) \mathrm{D}$ - concentration above $30 \mathrm{ng} / \mathrm{ml}$ [13]. Finally, most interventional studies reaching at least a level of $30 \mathrm{ng} / \mathrm{ml}$ have determined a fall risk reduction, whereas studies reaching mean concentration of $20 \mathrm{ng} / \mathrm{ml}$ did not [13]. Therefore, a target level of $\geq 30 \mathrm{ng} / \mathrm{ml}$ is regarded to be adequate for geriatric patients with high risk of falls and osteoporosis [14].

To our knowledge, the prevalence of vitamin D insufficiency and deficiency in frail older hospitalized patients is expected to be high but is not well studied and predictors are unknown. On the other hand, routine assessment of serum concentration of $25(\mathrm{OH}) \mathrm{D}$ status is very expensive, with costs of about $20 €$ per analysis. Accordingly, these resources could possibly be more effectively invested in a sufficient vitamin D supplementation, if the prevalence of vitamin D insufficiency is extremely high. Our hypothesis is that the prevalence of vitamin D insufficiency is extremely high among frail older hospitalized patients and immobility may be a predictor of vitamin D deficiency.

\section{Methods}

This study was part of a bigger study of 679 older participants (mean age $82.1 \pm 8.2$ and mean weight $70.5 \pm$ $17.6 \mathrm{~kg} ; 457$ females) [15]. In the current study, in order to measure the prevalence of vitamin D-deficiency and insufficiency and their association with the results of the geriatric assessment, we retrospectively analyzed the routine measurements of serum 25(OH)D of 217 older patients which were consecutively hospitalized between 01.07.2016 and 31.10.2016 to a geriatric hospital ward. Serum 25(OH)D concentrations were obtained from the local laboratory data base. The measurements were performed at hospital admission with an electrochemiluminescence immunoassay (ECLIA) on Cobas 8000 (e602), Roche, Mannheim, Germany. Serum 25(OH)D concentrations below $20 \mathrm{ng} / \mathrm{ml}$ were regarded as deficiency, concentrations between 20 and $29.99 \mathrm{ng} / \mathrm{ml}$ were classified as insufficiency and concentrations of $30 \mathrm{ng} / \mathrm{ml}$ and above were considered as desirable.

In addition, results of the routine geriatric assessment including Barthel-Index, Mini Mental State Examination (MMSE), the 15 item Geriatric Depression Scale (GDS-15), Mini Nutritional Assessment Short Form (MNA-SF) as well as previous intake of vitamin D supplementation were derived from the patients' medical records. Briefly, the range of the German version of the Barthel-Index is 0-100 pts., with 100 pts. indicating independency in all activities of daily living [16, 17]. MNA-SF [18] was used for nutritional assessment and subjects were grouped as malnourished ( $0-7$ points), at risk of malnutrition (8-11 points) and having normal nutritional status (12-14 points). Depression was investigated by the use of the GDS-15 [19] with the score $<6$ as normal emotional status and a cognitive status was assessed using the MMSE [20] with the score $\geq 24$ as normal cognitive. All assessments were performed soon after hospital admission.

\section{Statistical analysis}

The statistical analysis was performed with SPSS statistical software (SPSS Statistics for Windows, IBM Corp, Version 23.0, Armonk, NY, USA). Continuous variables are reported by their means and standard deviations (SDs) for normally distributed variables and median values with interquartile ranges (IQR) were expressed for non-normaly distributed data. Categorical variables are expressed as absolute numbers and relative frequencies (\%). A group comparison was performed using the $t$-test for continuous data with normal distribution, the Mann-Whitney $U$ test for continuous variables with non-normal distribution and Pearson Chi-square test for categorical variables. A stepwise binary logistic regression model was performed to assess the simultaneous effects of age, gender and geriatric assessments (i.e. Barthel-Index, MMSE, GDS-15 and MNA-SF) on the prevalence of low vitamin D. A $P$-value of $<0.05$ was considered as the limit of significance.

\section{Results}

Baseline characteristics of study participants stratified by different serum $25(\mathrm{OH}) \mathrm{D}$ concentrations are presented in in Table 1. The mean age of the participants was 81.6 years and median Barthel-Index and MMSE were 40 pts. and 24 pts., respectively, representing a frail older population of hospital patients. In total population, mean serum 25(OH)D was $12.7 \mathrm{ng} / \mathrm{ml} .168$ (77.4\%) patients had serum 25(OH)D concentrations below $20 \mathrm{ng} / \mathrm{ml}$ whereas, only 26 (12\%) participants 
Table 1 Characteristics of study participants stratified according to different serum 25(OH)D levels

\begin{tabular}{|c|c|c|c|c|c|}
\hline & All & $\begin{array}{l}\text { Deficiency } \\
(<20 \mathrm{ng} / \mathrm{ml})\end{array}$ & $\begin{array}{l}\text { Insufficiency } \\
(20-29.99 \mathrm{ng} / \mathrm{ml})\end{array}$ & $\begin{array}{l}\text { Normal } \\
(\geq 30 \mathrm{ng} / \mathrm{ml})\end{array}$ & $P$ value \\
\hline Total, N (\%) & $217(100)$ & $168(77.4)$ & $23(10.6)$ & $26(12.0)$ & \\
\hline Female, N (\%) & $152(70.0)$ & $112(73.7)$ & $18(11.8)$ & $22(14.5)$ & 0.117 \\
\hline Male, N (\%) & $65(30.0)$ & $56(86.2)$ & $5(7.7)$ & $4(6.2)$ & \\
\hline Age, years & $81.6 \pm 8.0$ & $81.4 \pm 8.3$ & $83.3 \pm 5.8$ & $81.7 \pm 8.3$ & 0.494 \\
\hline Vitamin 25(OH)D, ng/ml & $12.7 \pm 12.9$ & $6.8 \pm 5.2$ & $24.0 \pm 2.9$ & $40.7 \pm 9.3$ & 0.001 \\
\hline $\begin{array}{l}25(\mathrm{OH}) \mathrm{D} \text { supplementation } \\
+, \mathrm{N}(\%)\end{array}$ & $50(23.0)$ & $22(44.0)$ & $9(18.0)$ & $19(38.0)$ & \\
\hline $\begin{array}{l}25(\mathrm{OH}) \mathrm{D} \text { supplementation } \\
-, \mathrm{N}(\%)\end{array}$ & $167(77.0)$ & $146(87.4)$ & $14(8.4)$ & $7(4.2)$ & 0.001 \\
\hline Barthel-Index, pts. & $40(30-50)$ & $40(25-55)$ & $35(25-45)$ & $40(35-55)$ & 0.446 \\
\hline MMSE, pts. & $24(19-27)$ & $23(19-27)$ & $25(21-27)$ & $24(16-27)$ & 0.472 \\
\hline GDS-15, pts. & $2(0-3)$ & $3(1-3)$ & $1(0-3)$ & $2(0-3)$ & 0.052 \\
\hline MNA-SF, pts. & $8(6-10)$ & $8(6-10)$ & $9(7-10)$ & $9(5-10)$ & 0.427 \\
\hline
\end{tabular}

25(OH)D supplementation +, previous $25(\mathrm{OH})$ supplementation; $25(\mathrm{OH}) \mathrm{D}$ supplementation -, no previous $25(\mathrm{OH})$ supplementation; MMSE Mini-Mental-State-Examination GDS-15 15-item geriatric depression scale, MNA-SF Mini-Nutritional-Assessment short form; Values are given as number (\%), mean \pm SD or median (interquartile range)

had desirable serum 25(OH)D concentrations above $30 \mathrm{ng} / \mathrm{ml}$ (Table 1).

According to the patients' medical records, there was evidence for previous intake of vitamin D supplementation in 50 patients in which 19 (38\%) participants had sufficient concentrations above $30 \mathrm{ng} / \mathrm{ml}$. However, doses and duration of vitamin D supplementation was unspecified in this group. In addition, in the group without previous vitamin D supplementation based on the patients' medical records, 146 (87.4\%) and $14(8.4 \%)$ were vitamin D deficient and vitamin D insufficient respectively, whereas only 7 (4.2\%) patients showed desirable concentrations of $30 \mathrm{ng} / \mathrm{ml}$ and above.

In a stepwise logistic regression analysis, the effects of age, gender and results of geriatric assessment (as independent variables) on the prevalence of low vitamin D were tested (Table 2). Only previous intake of

Table 2 Binary logistic regression analysis of factors associated with serum $25(\mathrm{OH}) \mathrm{D}$ deficiency

\begin{tabular}{lllll}
\hline & Beta Coefficient & SE & OR $(95 \% \mathrm{Cl})$ & $P$ value \\
\hline Age & -0.013 & 0.037 & $0.987(0.918-1.061)$ & 0.728 \\
Gender & -1.150 & 0.738 & $0.317(0.075-1.345)$ & 0.119 \\
25(OH)D suppl.+ & -2.174 & 0.704 & $0.114(0.029-0.453)$ & 0.002 \\
Barthel-Index & 0.015 & 0.019 & $1.015(0.978-1.052)$ & 0.434 \\
MMSE & -0.059 & 0.056 & $0.943(0.844-1.053)$ & 0.296 \\
GDS-15 & 0.390 & 0.182 & $1.477(1.034-2.110)$ & 0.032 \\
MNA-SF & -0.102 & 0.109 & $0.903(0.730-1.117)$ & 0.349 \\
\hline
\end{tabular}

25(OH)D suppl.+ Previous vitamin D supplementation, MMSE Mini-MentalState-Examination, GDS-15 15-item geriatric depression scale, MNA-SF MiniNutritional-Assessment short form, OR Odds ratio, SE Standard error vitamin D supplementation and high GDS-15 score were significantly associated with vitamin D deficiency.

\section{Discussion}

The prevalence of vitamin D deficiency is generally considered to be high, even in the general population. In the National Health and Nutrition Examination Survey (NHANES), 41.6\% of adult participants showed 25(OH)D concentrations $<20 \mathrm{ng} / \mathrm{ml}$ [21]. Due to decreased sunlight exposure and lower capacity of skin synthesis, the prevalence rates of vitamin D deficiency in older subjects could be expected to be even higher, especially in frail older hospitalized patients, as observed in our study cohort. In the current study, in the subgroup without recorded previous vitamin D supplementation, only $4.2 \%$ of participants showed desirable vitamin $\mathrm{D}$ concentrations. The prevalence data of our study cohort was comparable to three other existing studies in older hospitalized patients. In 412 orthogeriatric patients (mean age 80 years) with hip fracture in Singapore, vitamin D deficiency was present in $57.5 \%$, vitamin D insufficiency in $34.5 \%$ and only $8 \%$ had desirable vitamin D concentrations $>30 \mathrm{ng} / \mathrm{ml}$ [11]. However, in that study only being housebound and Malay ethnicity were associated with vitamin $\mathrm{D}$ deficiency in a multivariate model. In another study of 123 Portuguese hospitalized patients in Internal Medicine (mean age 71 years), 92.7\% presented with vitamin D deficiency and only $7.3 \%$ had concentrations $>20 \mathrm{ng} / \mathrm{ml}$ [22]. In addition, less than $5 \%$ of 332 hospital patients from Brussels (mean age 69 years) reached vitamin D concentrations $>30 \mathrm{ng} /$ $\mathrm{ml}$ [9]. Moreover, it is worth mentioning that serum concentrations of vitamin $\mathrm{D}$ differ considerably during the seasons, reaching to the highest level in late summer and 
to the lowest level in late winter [23]. In a study of 4149 participants (aged 45-75 years) [24], the highest prevalence of vitamin D deficiency was observed in February/ March (92\%) whereas the lowest prevalence was seen in June/July (71\%). However, our recent study in older hospitalized patients [15] demonstrated neither monthly nor seasonal variations in vitamin $25(\mathrm{OH}) \mathrm{D}$ concentrations; indicating that sunlight dependent skin synthesis is unlikely to contribute to vitamin D status in these patients. Therefore, supplementation seems to be necessary to maintain desirable vitamin D concentrations among this population throughout the year.

Due to high prevalence of vitamin D deficiency and insufficiency observed in our study and previous studies in hospital patients, it appears abdicable to measure vitamin D concentrations before initiation of supplementation in frail older hospitalized patients, because the pretest-probability for low serum-levels is 96\%. Even predictive models which have been applied in community dwelling older subjects [25] appear impractical in our study population, as simply the hospital setting in frail older patients with the absence of previous supplementation reveals a $96 \%$ risk of having no adequate vitamin D level. In the present study, due to the very heterogenic study cohort, neither parameters of mobility nor nutritional assessment were linked to serum $25(\mathrm{OH}) \mathrm{D}$ concentrations. In addition, many of the patients suffered from acute disease in order that the Barthel-Index obtained on admission does not reflect their previous mobility. Furthermore, the significant association of vitamin D deficiency with a higher score of the geriatric depression scale is not surprising, since vitamin $\mathrm{D}$ deficiency has been linked to depression in many cross-sectional studies [26, 27]. However, there is a lack of evidence for its causality in interventional trials [27]. In a study of 1282 older patients aged 65 to 95 years, Hoogendijk et al. [28] indicated that serum concentrations of $25(\mathrm{OH}) \mathrm{D}$ were $14 \%$ lower in both groups with minor and major depression. Eyles et al. [29] reviewed the possible association between low levels of vitamin D and neuropsychiatric diseases and demonstrated that vitamin D insufficiency or deficiency may impact on various neurotransmitter targets (namely, dopamine, noradrenaline and adrenaline). In addition, in some cross-sectional studies [30, 31], no relationship was observed between depression and vitamin D deficiency after considering the lifestyle factors such as time spent outside and the degree of sun exposure.

In general, testing for a condition which is prevalent in $96 \%$ of patients appears to be ineffective, especially if the condition may be mastered by supplementation at low costs and without side effects. However, there is controversy regarding the dose of vitamin $\mathrm{D}_{3}$ supplementation in achieving optimal serum $25(\mathrm{OH}) \mathrm{D}$ concentrations.
Vitamin $\mathrm{D}_{2}$ in the dose range of 200,000 to $300,000 \mathrm{IU}$ was effective in increasing mean $25(\mathrm{OH}) \mathrm{D}$ concentrations at 12 weeks in older frail patients who had low $25(\mathrm{OH}) \mathrm{D}$ concentrations at baseline [32] or a long-term efficacy of a 500,000 IU dose vitamin $\mathrm{D}_{3}$ were similarly effective in stabilizing the $25(\mathrm{OH}) \mathrm{D}$ concentration above $30 \mathrm{ng} / \mathrm{mL}$ at 12 weeks in older women [3]. In addition, in a recent study on vitamin $\mathrm{D}$ supplementation in older patients with low-trauma falls [5], the serum $25(\mathrm{OH}) \mathrm{D}$ concentrations increased by $12.7 \mathrm{ng} / \mathrm{ml}$ at 6 months with a dose of 24,000 IU per month. Therefore, we would not expect desirable serum concentrations before 6 months of supplementation at a daily dose of 800 to $1000 \mathrm{IU}$ in frail older hospitalized patients without previous supplementation. We would therefore recommend initiating vitamin $\mathrm{D}$ supplementation in this population without testing the serum concentrations and assessing serum levels after 6 months of supplementation. When the serum $25(\mathrm{OH}) \mathrm{D}$ concentrations do not rise above $30 \mathrm{ng} /$ $\mathrm{ml}$, supplementation should be continued with an increased dose.

Previous studies have demonstrated the statistically significant decrease in the risk of falls and fractures associated with administration of vitamin D among older individuals $[2,33]$. In a randomized controlled trial comprising 625 older people, Flicker et al. [33] revealed that administration of ergocalciferol 10,000 IU once weekly and then 1000 IU daily decreased the risk of fractures and falls. However, detrimental impact of high dose of vitamin $\mathrm{D}$ supplementation was observed in a several studies [3, 4]. Annual oral administration of 500,000 IU cholecalciferol in 2265 community-dwelling women (aged $\geq 70$ years) was followed by an increased risk of falls and fractures [3]. Consequently we do not recommend a high dose treatment.

Some limitations of the present study need to be mentioned. First, it is the retrospective methodology and we did not assess some factors such as BMI or dietary habits of the patients. Second, we have no information about the duration, doses and compliance of previous vitamin D supplementation. As the data were derived from the patients' medical records, it cannot be excluded that some subjects had previous vitamin D supplementation without respective information in the record. Third, frailty was not defined by exact frailty criteria, but the results of the geriatric assessment and our experience with these patients indicate an entirely frail cohort. Finally, the relatively small sample size of total population may have limited the value of our results.

\section{Conclusion}

Almost $96 \%$ of patients had serum 25(OH)D concentrations below desirable concentrations of $\geq 30 \mathrm{ng} / \mathrm{ml}$. 
Since the pretest-probability of insufficient vitamin D levels in the group of frail older hospitalized patients is $96 \%$, the measurement of serum vitamin D concentrations appears to be abdicable before the initiation of supplementation. Therefore, testing of serum 25(OH)D should be used for monitoring of supplementation rather than giving the indication for the initiation of supplementation in frail older hospitalized patients.

\section{Abbreviation}

25 (OH)D: 25-hydroxyvitamin D; GDS-15: Geriatric Depression Scale: IQR: Interquartile ranges; MMSE: Mini Mental State Examination; MNASF: Mini Nutritional Assessment Short Form; PTH: Parathyroid hormone; SDs: Standard deviations

\section{Availability of data and materials}

The datasets used and analyzed during the current study are available from the corresponding author on reasonable request.

\section{Authors' contributions}

MP and RW designed the study. RW obtained the data. SFB, MP and RW prepared the manuscript. BA, CNK, ALMW, AS, LS, BW and MZ collectively performed the data analysis and reviewed the final manuscript. All authors read and approved the final manuscript.

\section{Ethics approval and consent to participate}

The study was performed in accordance with the declaration of Helsinki and was approved by the ethical committee of Ruhr-University Bochum. The participant consent is not applicable due to retrospective methodology.

\section{Consent for publication}

Not applicable.

\section{Competing interests}

The authors declare that they have no competing interests.

\section{Publisher's Note}

Springer Nature remains neutral with regard to jurisdictional claims in published maps and institutional affiliations.

Received: 30 June 2017 Accepted: 16 September 2018

Published online: 20 September 2018

\section{References}

1. Murad MH, Elamin KB, Abu Elnour NO, Elamin MB, Alkatib AA, Fatourech MM, Almandoz JP, Mullan RJ, Lane MA, Liu H, et al. Clinical review: the effect of vitamin D on falls: a systematic review and meta-analysis. J Clin Endocrinol Metab. 2011;96(10):2997-3006.

2. Zheng YT, Cui QQ, Hong YM, Yao WG. A meta-analysis of high dose, intermittent vitamin D supplementation among older adults. PLoS One. 2015;10(1):e0115850

3. Sanders KM, Stuart AL, Williamson EJ, Simpson JA, Kotowicz MA, Young D, Nicholson GC. Annual high-dose oral vitamin D and falls and fractures in older women: a randomized controlled trial. Jama. 2010;303(18):1815-22.

4. Smith H, Anderson F, Raphael H, Maslin P, Crozier S, Cooper C. Effect of annual intramuscular vitamin $\mathrm{D}$ on fracture risk in elderly men and women--a population-based, randomized, double-blind, placebo-controlled trial. Rheumatology (Oxford, England). 2007;46(12):1852-7.

5. Bischoff-Ferrari HA, Dawson-Hughes B, Orav EJ, Staehelin HB, Meyer OW, Theiler R, Dick W, Willett WC, Egli A. Monthly high-dose vitamin D treatment for the prevention of Functional decline: a randomized clinical trial. JAMA Intern Med. 2016;176(2):175-83.

6. Witte KK, Byrom R, Gierula J, Paton MF, Jamil HA, Lowry JE, Gillott RG, Barnes SA, Chumun H, Kearney LC, et al. Effects of vitamin D on cardiac function in patients with chronic HF: the VINDICATE study. J Am Coll Cardiol. 2016;67(22):2593-603.
7. Czernichow S, Fan T, Nocea G, Sen SS. Calcium and vitamin D intake by postmenopausal women with osteoporosis in France. Curr Med Res Opin. 2010;26(7):1667-74.

8. MacLaughlin J, Holick MF. Aging decreases the capacity of human skin to produce vitamin D3. J Clin Invest. 1985;76(4):1536-8.

9. Daoudi N, Karmali R, Fuss M. Evaluation of vitamin D deficiency in hospitalized patients in Brussels. Rev Med Brux. 2009;30(1):5-10.

10. Mithal A, Wahl DA, Bonjour JP, Burckhardt P, Dawson-Hughes B, Eisman JA, El-Hajj Fuleihan G, Josse RG, Lips P, Morales-Torres J, et al. Global vitamin D status and determinants of hypovitaminosis D. Osteoporos Int. 2009;20(11): 1807-20.

11. Ramason R, Selvaganapathi N, Ismail NH, Wong WC, Rajamoney GN, Chong MS. Prevalence of vitamin d deficiency in patients with hip fracture seen in an orthogeriatric service in sunny Singapore. Geriatric orthopaedic surgery \& rehabilitation. 2014:5(2):82-6.

12. Rosen CJ, Abrams SA, Aloia JF, Brannon PM, Clinton SK, Durazo-Arvizu RA, Gallagher JC, Gallo RL, Jones G, Kovacs CS, et al. IOM committee members respond to Endocrine Society vitamin D guideline. J Clin Endocrinol Metab. 2012:97(4):1146-52.

13. Holick MF, Binkley NC, Bischoff-Ferrari HA, Gordon CM, Hanley DA, Heaney $\mathrm{RP}$, Murad $\mathrm{MH}$, Weaver $\mathrm{CM}$. Guidelines for preventing and treating vitamin D deficiency and insufficiency revisited. J Clin Endocrinol Metab. 2012; 97(4):1153-8

14. Holick MF, Binkley NC, Bischoff-Ferrari HA, Gordon CM, Hanley DA, Heaney RP, Murad MH, Weaver CM, Endocrine S. Evaluation, treatment, and prevention of vitamin D deficiency: an Endocrine Society clinical practice guideline. J Clin Endocrinol Metab. 2011;96(7):1911-30.

15. Pourhassan $M$, Wirth $R$. Seasonal variation in vitamin $D$ status among frail older hospitalized patients. J Frailty Aging. 2018;7(2):95-9

16. Lubke N, Meinck M, Von Renteln-Kruse W. The Barthel Index in geriatrics. A context analysis for the Hamburg classification manual. Z Gerontol Geriatr. 2004;37(4):316-26.

17. Mahoney FI, Barthel DW. Functional Evaluation: the Barthel Index. Md State Med J. 1965:14:61-5.

18. Kaiser MJ, Bauer JM, Ramsch C, Uter W, Guigoz Y, Cederholm T, Thomas DR, Anthony $\mathrm{P}$, Charlton KE, Maggio M, et al. Validation of the mini nutritional assessment short-form (MNA-SF): a practical tool for identification of nutritional status. J Nutr Health Aging. 2009:13(9):782-8.

19. D'Ath P, Katona P, Mullan E, Evans S, Katona C. Screening, detection and management of depression in elderly primary care attenders. I: the acceptability and performance of the 15 item geriatric depression scale (GDS15) and the development of short versions. Fam Pract. 1994;11(3): 260-6.

20. Folstein MF, Folstein SE, McHugh PR. "mini-mental state". A practical method for grading the cognitive state of patients for the clinician. J Psychiatr Res. 1975;12(3):189-98.

21. Forrest $K Y$, Stuhldreher WL. Prevalence and correlates of vitamin $D$ deficiency in US adults. Nutrition research (New York, NY). 2011;31(1):48-54.

22. Santiago T, Rebelo M, Porto J, Silva N, Vieira J, Nascimento Costa JM. Hypovitaminosis D in patients admitted to an internal medicine ward. Acta Medica Port. 2012;25(2):68-76.

23. Adams JS, Hewison M. Update in Vitamin D. J Clin Endocrinol Metabol. 2010:95(2):471-8

24. Schramm S, Lahner H, Jockel KH, Erbel R, Fuhrer D, Moebus S, Grp HNRS. Impact of season and different vitamin D thresholds on prevalence of vitamin D deficiency in epidemiological cohorts-a note of caution. Endocrine. 2017:56(3):658-66.

25. Lopes JB, Fernandes GH, Takayama L, Figueiredo CP, Pereira RM. A predictive model of vitamin D insufficiency in older community people: from the Sao Paulo Aging \& Health Study (SPAH). Maturitas. 2014;78(4):335-40.

26. Parker GB, Brotchie H, Graham RK. Vitamin D and depression. J Affect Disord. 2017;208:56-61.

27. Jovanova O, Aarts N, Noordam R, Carola-Zillikens M, Hofman A, Tiemeier $H$. Vitamin D serum levels are cross-sectionally but not prospectively associated with late-life depression. Acta Psychiatr Scand. 2017; 135:185-94.

28. Hoogendijk WJ, Lips P, Dik MG, Deeg DJ, Beekman AT, Penninx BW. Depression is associated with decreased 25-hydroxyvitamin D and increased parathyroid hormone levels in older adults. Arch Gen Psychiatry. 2008;65(5):508-12. 
29. Eyles DW, Burne TH, McGrath JJ. Vitamin D, effects on brain development, adult brain function and the links between low levels of vitamin $D$ and neuropsychiatric disease. Front Neuroendocrinol. 2013;34(1):47-64.

30. Lee DM, Tajar A, O'Neill TW, O'Connor DB, Bartfai G, Boonen S, Bouillon R, Casanueva FF, Finn JD, Forti G, et al. Lower vitamin D levels are associated with depression among community-dwelling European men. J Psychopharmacol (Oxford, England). 2011;25(10):1320-8.

31. Zhao G, Ford ES, Li C, Balluz LS. No associations between serum concentrations of 25-hydroxyvitamin D and parathyroid hormone and depression among US adults. Br J Nutr. 2010;104(11):1696-702.

32. Latham NK, Anderson CS, Lee A, Bennett DA, Moseley A, Cameron ID. A randomized, controlled trial of quadriceps resistance exercise and vitamin $\mathrm{D}$ in frail older people: the frailty interventions trial in elderly subjects (FITNESS). J Am Geriatr Soc. 2003;51(3):291-9.

33. Flicker L, Maclnnis RJ, Stein MS, Scherer SC, Mead KE, Nowson CA, Thomas J, Lowndes C, Hopper JL, Wark JD. Should older people in residential care receive vitamin $\mathrm{D}$ to prevent falls? Results of a randomized trial. J Am Geriatr Soc. 2005;53(11):1881-8

Ready to submit your research? Choose BMC and benefit from:

- fast, convenient online submission

- thorough peer review by experienced researchers in your field

- rapid publication on acceptance

- support for research data, including large and complex data types

- gold Open Access which fosters wider collaboration and increased citations

- maximum visibility for your research: over $100 \mathrm{M}$ website views per year

At $\mathrm{BMC}$, research is always in progress.

Learn more biomedcentral.com/submissions 